\title{
Isoenzymatic characterization of Colletotrichum kahawae isolates with different levels of aggressiveness
}

\author{
Andreia Loureiro ${ }^{1,2}$, Leonor Guerra-Guimarães ${ }^{1}$, Fernando C. Lidon², Benoit Bertrand ${ }^{3}$, Maria C. \\ Silva $^{1}$ \& Vítor Várzea ${ }^{1}$
}

${ }^{1}$ Instituto de Investigação Científica Tropical, Centro de Investigação das Ferrugens do Cafeeiro (CIFC), Quinta do Marquês, 2784-505, Oeiras, Portugal; ${ }^{2}$ Grupo de Disciplinas de Ecologia da Hidrosfera, Faculdade de Ciências e Tecnologia, Universidade Nova de Lisboa, 2825-114, Caparica, Portugal; ${ }^{3}$ Centre International de Recherches Agronomiques pour le Développement (CIRAD), UMR RPB, IRD-CIRAD-UM2, BP 64501-34394, Montpellier, France

Author for correspondence: Andreia Loureiro, e-mail: andreiasofialoureiro@gmail.com

\begin{abstract}
The hemibiotrophic fungus Colletotrichum kahawae is the causal agent of Coffee Berry Disease - CBD, an economically devastating disease restricted to Arabica coffee production in Africa. Understanding pathogen variability is crucial for the implementation of disease control measures. In this study, six isoenzymatic systems (esterase, acid and alkaline phosphatase, malate dehydrogenase, peroxidase and superoxide dismutase) were used to assess the genetic variation among 12 C. kahawae isolates (from different geographic origins and with different levels of aggressiveness towards coffee) and one Colletotrichum gloeosporioides isolate (not pathogenic to green berries). Cluster analysis of the banding profiles obtained for the six enzymes enabled the differentiation of the two species and revealed the existence of intraspecific variability among $C$. kahawae isolates. Alkaline phosphatase was the most discriminative enzyme, allowing also the discrimination between the most and least aggressive isolates of C. kahawae.
\end{abstract}

Key words: Coffee berry disease, isoelectric focusing, isoenzymes, variability.

\section{INTRODUCTION}

Coffee berry disease (CBD), caused by the fungus Colletotrichum kahawae J. M. Waller \& P. D. Bridge, is currently restricted to Arabica coffee (Coffea arabica L.) in Africa. CBD is still a quarantine disease with the foreseen threat of one day becoming a problem in Latin America and Asia, especially in high-altitude coffee producing areas where climatic conditions appear to be favourable for fungus development. During prolonged wet and cold weather, this disease can quickly destroy $50-80 \%$ of the developing green berries (Van der Vossen \& Walyaro, 2009). C. kahawae is closely related to $C$. gloeosporioides, which also occurs (along with $C$. acutatum) as a saprophyte in the coffee mycobiota (Waller \& Masaba, 2006). Considering that CBD is a major threat to Arabica coffee, the accurate and timely identification of the pathogen becomes extremely important to the coffee industry and to the maintenance of plant health (Bridge et al., 2008).

Like other Colletotrichum species, C. kahawae differentiation and variability has been studied considering morphological, cultural and pathogenic characteristics, vegetative compatibility groups (VCG) and also molecular and isoenzymatic studies (Omondi et al., 2000; Várzea et al., 2002; Derso \& Waller, 2003; Silva et al., 2006; Bridge et al., 2008). Pathogenic tests using isolates from several
African countries and various coffee genotypes revealed aggressiveness variation among $C$. kahawae isolates (Manga et al., 1997; Omondi et al., 2000). Small differences between East and West Africa isolates were detected when using VCG (Várzea et al., 2002; Bridge et al., 2008).

Low variability was observed when several molecular techniques, such as random amplified polymorphic DNA (RAPD), restriction fragment length polymorphisms (RFLP), inter-simple sequence repeat (ISSR), variable number of tandem repeats (VNTR) and amplified fragment length polymorphisms (AFLP) were used to study C. kahawae isolates (Derso \& Waller, 2003; Bridge et al., 2008; Manuel et al., 2010). Recently, Silva et al. (2010), combining information from a multi-locus analysis ( $\beta$-tubulin2, ITS and MAT1-2-1 genes), were able to discriminate $C$. kahawae isolates in three divergent but clonal geographical groups: Angola, Cameroon and East Africa, confirming the low genetic variability within $C$. kahawae.

Regarding C. kahawae, and despite the low variability found at the molecular level, preliminary studies based on $\alpha$-esterase and acid phosphatase profiles obtained by isoelectric focusing (IEF) electrophoresis revealed the existence of some variability among isolates (Várzea, 1995; Loureiro et al., 2004). Isoenzymatic analyses were successfully used to study intraspecific variations and also 
to establish interspecific differences among Colletotrichum species (Bonde et al., 1991, Rego et al., 1994; Lima \& Menezes, 2002; Lima Filho et al., 2003; Horvath \& Vargas, 2004).

By increasing the number of enzymes tested and using a different set of isolates from different geographical origins, the present study aimed to enhance the usefulness of isoenzyme analysis to determine the variation between C. kahawae isolates with different levels of aggressiveness. Six isoenzymatic systems were studied by IEF and each isolate aggressiveness was tested.

\section{MATERIAL AND METHODS}

\section{Fungal isolates}

Single spore isolates of $C$. kahawae obtained from coffee berries came from Angola (Ang6), Ethiopia (Eti17), Malawi (Ma12), Rwanda (Rua1), Tanzania (Tan1), Kenya (Que2, Que48, Que70, Que71, Que72), Cameroon (Cam1), and Zimbabwe (Zim1), and one isolate of C. gloeosporioides obtained from coffee berries came from China (Chi1). The isolates were maintained in malt extract agar (Oxoid) 3.4\%, at room temperature.

\section{Aggressiveness test}

Detached expanding green berries of the variety Caturra were inoculated with Colletotrichum isolates grown at $25^{\circ} \mathrm{C}$, according to the technique described by Van der Vossen et al. (1976), with slight modifications. The green berries were placed on trays, lying down on a nylon sponge and inoculated with a $5 \mu \mathrm{L}$-drop of conidia suspension $\left(2 \times 10^{6} / \mathrm{mL}\right)$, obtained from 10-dayold cultures. Covered trays were placed in a Phytotron $750 \mathrm{E}$ (Aralab, Portugal) at $22^{\circ} \mathrm{C}$, incubated for the first $24 \mathrm{~h}$ in the dark and then kept with a photoperiod of $12 \mathrm{~h}$. The number of days between inoculation, the appearance of the first symptoms and the index of disease intensity (IDI) 10 days after inoculation were recorded. The IDI was calculated based on a $0-8$ disease severity scale (Table 1), using the formula IDI $=\sum$ (number of green berries in each class $\mathrm{x}$ numeric value of each class) / (total number of green berries $x$ eight). Thirty green berries were

TABLE 1 - Scale of disease classification used to calculate the index of disease intensity

\begin{tabular}{ll}
\hline \hline Class & \multicolumn{1}{c}{ Description } \\
\hline 0 & Green berries without symptoms \\
1 & Black points in the inoculation spot $(1-2 \mathrm{~mm})$ \\
2 & Black lesions with approximately $3 \mathrm{~mm}$ diameter \\
3 & Black lesions with approximately $5 \mathrm{~mm}$ diameter \\
4 & Black lesions with approximately $7 \mathrm{~mm}$ diameter \\
5 & Black lesions with approximately $10 \mathrm{~mm}$ diameter \\
6 & Black lesions with approximately $12 \mathrm{~mm}$ diameter \\
7 & Black lesions with approximately $15 \mathrm{~mm}$ diameter \\
8 & Whole berries covered with black lesions \\
\hline
\end{tabular}

tested for each isolate. C. gloeosporioides was used as a negative control. The significance of aggressiveness was determined using Tukey's multiple range test $(\mathrm{P} \leq 0.05)$.

\section{Protein extraction}

Enzymatic extracts were obtained from the 13 isolates, grown in $50 \mathrm{~mL}$ of liquid medium (malt extract $30 \%$ and peptone $5 \%$ ) for 10 days at $25^{\circ} \mathrm{C}$, without agitation. Mycelium was collected on filter paper by vacuum filtration and washed several times with $\mathrm{dH}_{2} \mathrm{O}$, being thereafter homogenized with acetate buffer $(0.05 \mathrm{M}, \mathrm{pH}$ 4.5). The homogenate was centrifuged at $20000 \mathrm{~g}$ for $1 \mathrm{~h}$ at $4^{\circ} \mathrm{C}$. The supernatant was collected, dialyzed against water at $4^{\circ} \mathrm{C}$ overnight, and concentrated in polyethylene glycol (6000). The extract was stored at $-80^{\circ} \mathrm{C}$ until electrophoretic analysis. The protein content of each sample was determined according to the Bio-Rad (USA) protein assay kit.

\section{Electrophoresis and enzyme visualization}

Six enzymatic activities were studied by IEF electrophoresis, in a vertical slab $1.5 \mathrm{~mm}$ thick with $5 \%$ (w/v) polyacrylamide gel and 2\% ampholytes (Robertson et al., 1987): esterase (EST, EC3.1.1.2), alkaline phosphatase (ALP, EC3.1.3.1), acid phosphatase (ACP, EC3.1.3.2), malate dehydrogenase (MDH, EC1.1.1.37), peroxidase (POD, EC1.11.17) and superoxide dismutase (SOD, EC1.15.1.1). IEF was performed on a Mighty Small SE 250 apparatus (Hoefer, England) with electrode solutions containing $25 \mathrm{mM} \mathrm{NaOH}$ (catode) and $20 \mathrm{mM}$ acetic acid (anode) for all the enzymes. Electrophoresis was performed at a constant voltage of $200 \mathrm{~V}$ for $50 \mathrm{~min}$, followed by another $50 \mathrm{~min}$ at a constant voltage of $400 \mathrm{~V}$.

After migration, EST, ALP, ACP, MDH, POD and SOD were stained according to Nave \& Sauhey (1986), Guedes (1988), Scandalios (1969), Shawn \& Prasad (1970), Smith \& Hammerschmidt (1988) and Vallejos (1983), respectively.

\section{Enzyme analysis}

Data matrices from enzyme patterns were formed by identifying the presence (1) or absence (0) of a particular band. A genetic similarity matrix based on Jaccard's coefficient was calculated considering $S_{J}=a$ / $(a+b+c)$, where $a$ are bands present in both isolates being compared, $b$ are bands present only in the first isolate and $c$ are bands present only in the second isolate. A phenogram based on the estimated similarity coefficients was constructed by unweighed pair group method analysis (UPGMA), using the computer software package NTSYS-pc version 2.02 (Exeter Software, USA). The original similarity matrix was compared with the cophenetic value matrix generated from the systems of clusters. From the comparison of these two matrices, the cophenetic coefficient ( $r$ ) was estimated and used as fitting measurement. 


\section{RESULTS}

\section{Aggressiveness test}

All the C. kahawae isolates were virulent to the susceptible cultivar Caturra, causing dark sunken lesions, and the isolate Chi1 from C. gloeosporioides did not cause disease symptoms, as expected. The first disease symptoms occurred three days after inoculation on the green berries inoculated with the isolate Cam1 (Table 2). This isolate showed the highest IDI values (Table 2) and differed from the isolate Mal2 that only showed symptoms nine days after inoculation and displayed the lowest IDI (Table 2). The remained C. kahawae isolates formed a homogeneous group with IDI that did not differ from isolates Cam1 and Mal2.

\section{Isoenzymatic analysis}

The IEF electrophoresis of the six isoenzymatic systems were consistently visualized and clear patterns were detected for all the Colletotrichum isolates, and a total of 69 bands were assessed. For each enzyme tested the variation in the number of bands obtained per isolate and the respective range of isoelectric points were recorded (Table 3).

TheEST isoenzymatic patterns showed a high number of bands per isolate, with high degree of polymorphisms, except for isolate Cam 1 of $C$. kahawae for which only five bands were detected (Table 3 and Figure 1a). Based on the cluster analysis, isolates Cam1 of C. kahawae and Chi1 of $C$. gloeosporioides were clearly distinguished from the other isolates, and the values of the similarity coefficient were $23 \%$ and $38 \%$, respectively (Figure $2 a$ ).

For ACP, the number of bands varied from four to six for the C. kahawae isolates while only three bands were

TABLE 2 - Appearance of the first symptoms on green berries inoculated with Colletotrichum isolates, and index of disease intensity (IDI) ten days after inoculation

\begin{tabular}{|c|c|c|}
\hline Isolate & $\begin{array}{l}\text { Appearance of the first symptoms } \\
\text { (days after inoculation) }\end{array}$ & IDI \\
\hline & & $\begin{array}{c}25^{\circ} \mathrm{C} \\
(x \pm S D)\end{array}$ \\
\hline Ang6 & 4 & $0.23 \pm 0.09 \mathrm{ab}$ \\
\hline Cam1 & 3 & $0.44 \pm 0.15 \mathrm{~b}$ \\
\hline Eti17 & 5 & $0.33 \pm 0.07 \mathrm{ab}$ \\
\hline Mal2 & 9 & $0.005 \pm 0.003 \mathrm{a}$ \\
\hline Rua1 & 4 & $0.21 \pm 0.08 \mathrm{ab}$ \\
\hline Zim1 & 4 & $0.22 \pm 0.09 \mathrm{ab}$ \\
\hline Que2 & 5 & $0.17 \pm 0.01 \mathrm{ab}$ \\
\hline Que48 & 5 & $0.25 \pm 0.05 \mathrm{ab}$ \\
\hline Que71 & 5 & $0.19 \pm 0.01 \mathrm{ab}$ \\
\hline Que72 & 5 & $0.27 \pm 0.09 \mathrm{ab}$ \\
\hline Chi1 & - & - \\
\hline
\end{tabular}

${ }^{1}$ mean \pm standard deviation. ${ }^{2}$ According to Tukey's test $(\mathrm{P} \leq 0.05)$, in each column, different letters indicate significant differences.
TABLE 3 - Variation in the number of bands obtained per isolate and respective range of isoelectric points, for each enzyme tested

\begin{tabular}{lcc}
\hline \hline Enzyme & $\begin{array}{c}\text { Number of bands } \\
\text { (range) }\end{array}$ & $\begin{array}{c}\text { Isoelectric point } \\
\text { (range) }\end{array}$ \\
\hline Esterase & 5 to 15 & 3.4 to 7.9 \\
Acid phosphatase & 3 to 6 & 3.5 to 5.4 \\
Alkaline phosphatase & 2 to 6 & 4.2 to 5.4 and 7 \\
Malate dehydrogenase & 4 to 12 & 4.7 to 8.6 \\
Peroxidase & 1 to 5 & 3.8 to 9.5 \\
Superoxide dismutase & 1 to 2 & 4.6 to 5.9 \\
\hline
\end{tabular}

found for the $C$. gloeosporioides isolate (Table 3 and Figure 1b). Only isolates Cam1 and Que72 of C. kahawae and isolate Chi1 of $C$. gloeosporioides exhibited POD activity (Table 3 and Figure 1c). Two groups were identified when the SOD isoenzymatic pattern was analyzed: one characterized by the presence of two isoforms (pI 4.6 and 5.9) and another with only one isoform (pI 5.9) (Figure 1d). ACP, SOD and POD profiles were not useful to separate $C$. kahawae from $C$. gloeosporioides, and displayed low polymorphism among C. kahawae isolates (data not shown). However, despite the polymorphism found in the MDH system, expressed by a variation from four to 12 bands per isolate (Table 3, Figure 1e), this enzyme was also not helpful to distinguish C. kahawae from C. gloesporioides (data not shown). In the ALP isoenzymatic patterns the number of identified bands varied between two and six, with a predominance of four on $70 \%$ of the isolates (Figure 1f). There was one common band to all isolates. For this enzyme, the cluster analysis showed (Figure 2b) a clear separation of C. kahawae and $C$. gloeosporioides (similarity coefficient of $15 \%$ ). Among $C$. kahawae isolates, polymorphism was found with Cam1 and Mal2 showing a low similarity coefficient (38\% and 52\% respectively), compared to the remaining isolates (Figure $2 b)$.

Cluster analysis of the 13 Colletotrichum isolates based on the banding patterns obtained for the six enzymes clearly separated the two species (similarity coefficient of $34 \%$ ) (Figure 2c). Within cluster I, isolate Cam1 was clearly distinguished from the others (similarity coefficient of $37 \%$ ). The remaining isolates of cluster I could be separated in two subgroups with a $50 \%$ similarity. Group Ia integrates several isolates from Kenya (Que2, Que48, Que71, Que72), Angola (Ang6), Zimbabwe (Zim1), Malawi (Mal2) and Rwanda (Rua1), and group Ib joins two isolates, one from Tanzania (Tan1) and another from Kenya (Que70). The high correlation coefficient $(\mathrm{r}=0.93)$ showed that the dendrogram structure is a strong indicative of phenetic relationship among all the isolates.

\section{DISCUSSION}

The most distinctive characteristic of C. kahawae that enables it to occupy a unique ecological niche, and which separates it on a functional basis from all the other 


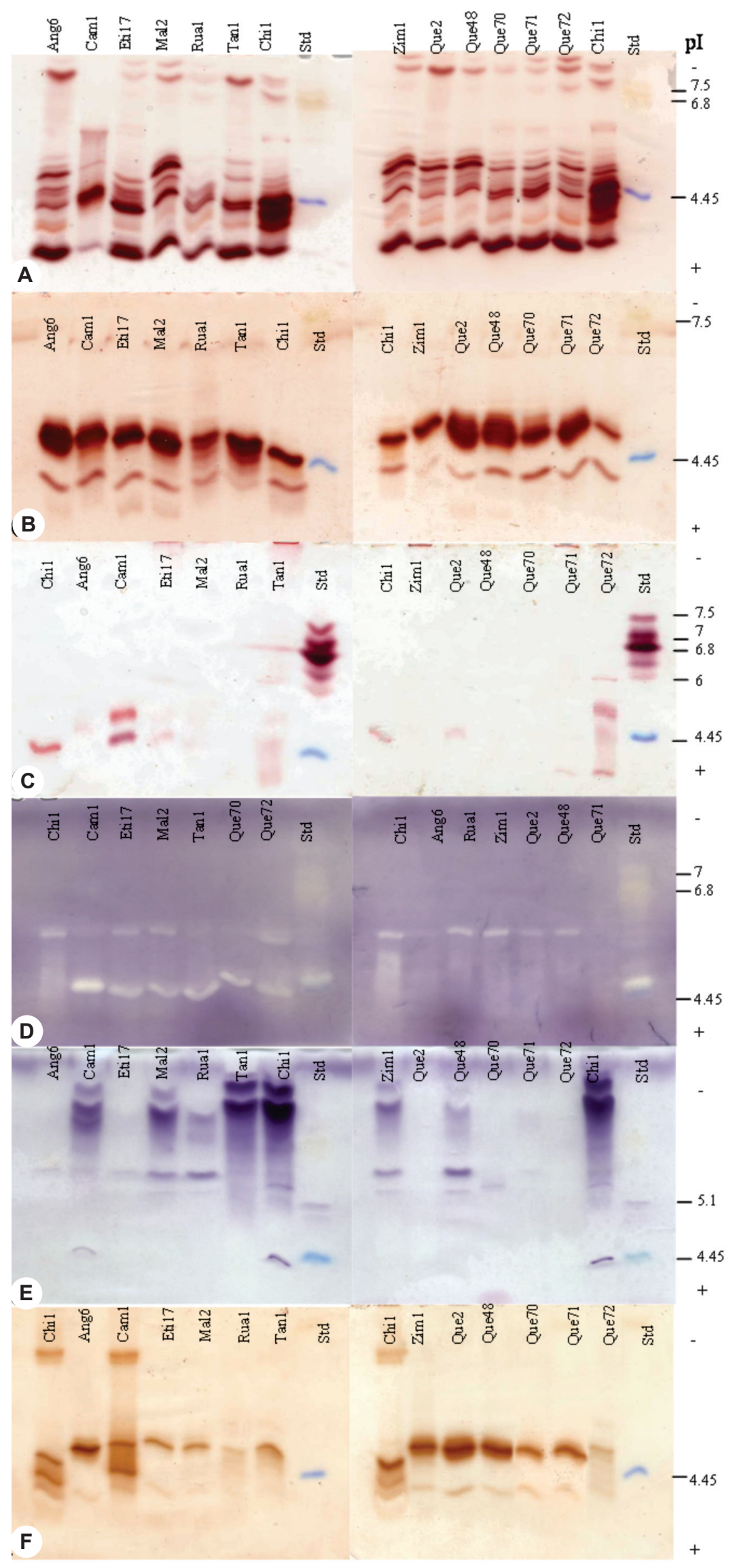

FIGURE 1 - A. Zymograms of esterase, B. acid phosphatase, C. peroxidases, D. superoxide dismutase, E. malate dehydrogenase and F. alkaline phosphatase isoenzymes of twelve Colletotrichum kahawae isolates: Ang6 (Angola), Cam1 (Cameroon), Eti17 (Ethiopia), Mal2 (Malawi), Rual (Rwanda), Tan1 (Tanzania), Zim1 (Zimbabwe), Que2, Que48, Que70, Que71, Que72 (Kenya) and one $C$. gloeosporioides isolate - Chil (China). Std - Isoelectric focusing standards broad range $\mathrm{pI}$ 4.45-9.6 (Bio-Rad). A-B and F. $10 \mu \mathrm{g}$ of protein were loaded per lane. C-D and E. $20 \mu \mathrm{g}$ of protein were loaded per lane. (-) Catode, (+) Anode. 


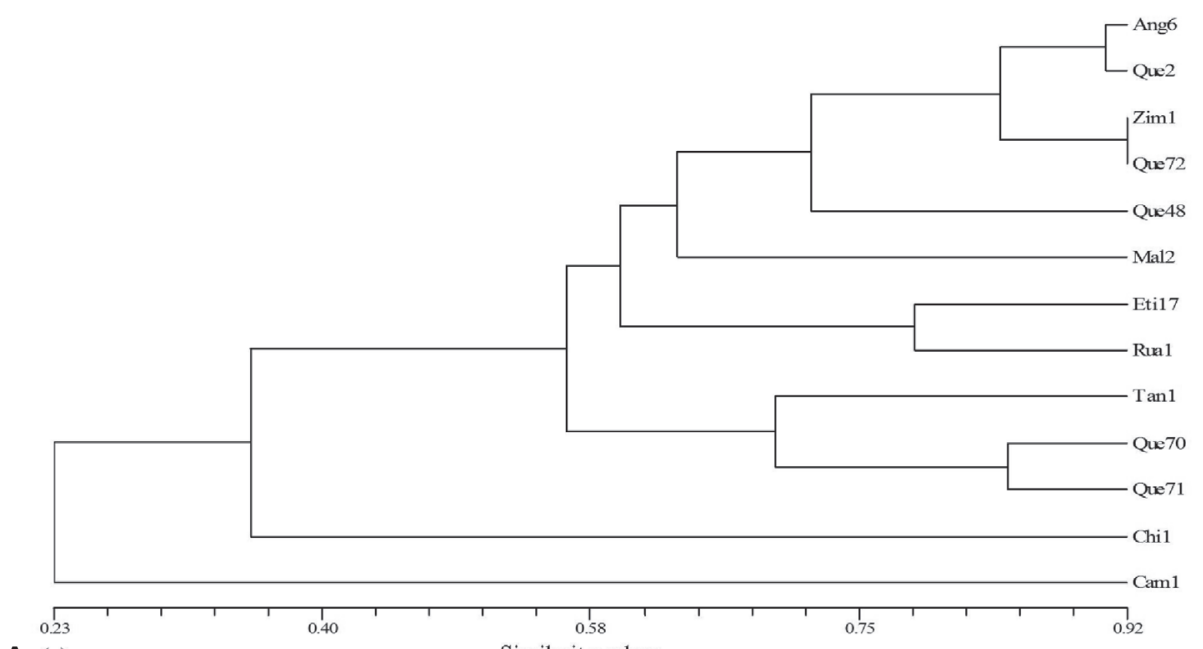

A

Similarity values
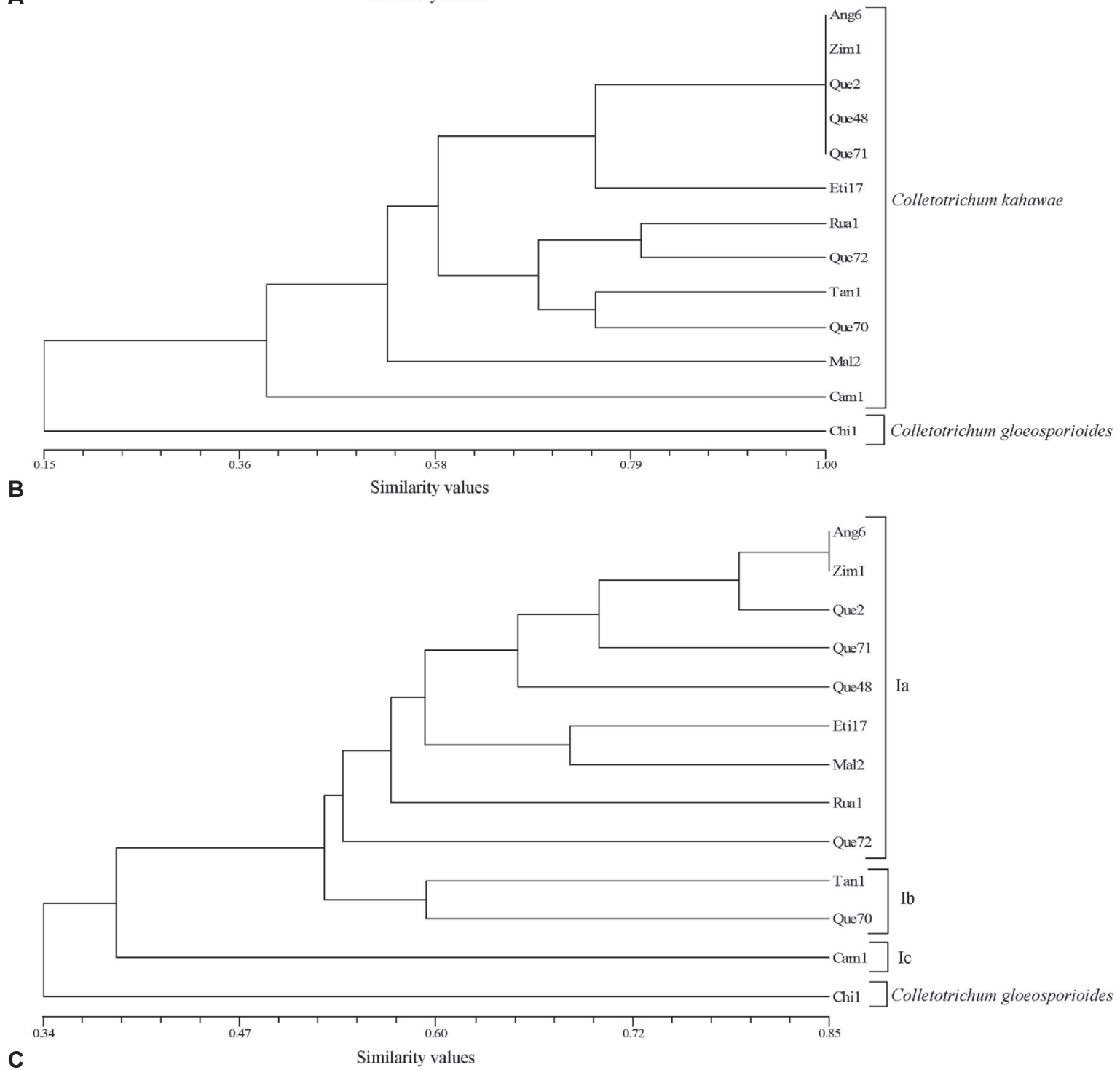

FIGURE 2 - Dendrogram resulting from cluster analysis of 12 Colletotrichum kahawae isolates and one C. gloeosporioides isolate, using Jaccard's similarity coefficient based on: A. esterase zymogram (cophenetic correlation coefficient $r=0.92819$ ); B. alkaline phosphatase zymogram (cophenetic correlation coefficient $r=0.94832$ ); C. esterase, acid and alkaline phosphatase, malate dehydrogenase, peroxidase and superoxide dismutase zymograms (cophenetic correlation coefficient $r=0.92866$ ). 
Colletotrichum species existing in coffee's microflora (namely Colletotrichum gloeosporioides and Colletotrichum acutatum), is its pathogenicity towards developing coffee berries and seedling hypocotyls (Waller et al., 1993). Our data confirmed that all C. kahawae isolates are pathogenic to green coffee berries and supported the importance of these pathogenicity tests to distinguish Colletotrichum species. As previously reported (Várzea et al., 1993; Manga et al., 1997; Várzea et al., 1999; Omondi et al., 2000), the C. kahawae isolates showed variability in their aggressiveness independently of the geographic origin. The fast development of the symptoms together with the highest IDI values revealed that isolate Cam1 was the most aggressive. Similar results were obtained by Várzea et al. (1999). C. kahawae isolate Cam1 was the most aggressive isolate compared to other CBD isolates, due to a higher sporulation capacity and rapid conidial germination in host tissues. Additionally, our data also pointed that isolate Mal2 was the least aggressive.

The isoenzymatic analysis further supported the usefulness of the IEF technique for investigating enzyme polymorphisms and genetic diversity within $C$. kahawae. Polymorphisms were detected almost in all the enzymes analysed, especially EST, ALP and MDH. The EST system yielded the greatest number of bands and exhibited a high degree of polymorphism, being efficient to differentiate C. kahawae from C. gloeosporioides. In a previous work (Omondi et al., 1997), EST isoenzymes also provided the differentiation of $C$. gloeosporioides, $C$. acutatum and $C$. kahawae isolates from coffee. ACP, SOD, POD and MDH zymograms did not allow the separation of C. kahawae from $C$. gloeosporioides. These data corroborated to some extent the close relationship between $C$. kahawae and $C$. gloeosporioides, as previously shown in several molecular studies (Abang et al., 2002; Lubbe et al., 2004). The ALP enzyme system showed a high level of intraspecific variability related to $C$. kahawae aggressiveness (particularly Cam1 and Mal2) and was effective to differentiate the $C$. gloeosporioides isolate (Chi1) from C. kahawae isolates. Bridge et al. (2008) reported different AFLP patterns and VCG for isolates collected in Cameroon and Malawi compared to other C. kahawae isolates. Isoenzyme profile analysis has been useful to investigate genetic diversity within Colletotrichum. Lima Filho et al. (2003), using EST and ACP enzyme patterns obtained by PAGE, reported intraspecific variability among $C$. gloeosporioides isolates from several tropical fruits. Additionally, Rios et al. (2004) successfully used the EST, ACP, ALP and MDH isoenzymes, to confirm the existence of genetic variability in C. lagenarium.

Cluster I contained all C. kahawae, while cluster II had the isolate Chil from C. gloeosporioides. Although no correlation between geographical origin and the subgroups formed was found, this study was more successful in detecting intraspecific variation among $C$. kahawae isolates as well as interspecific variability than other molecular studies performed (Abang et al., 2002; Lubbe et al., 2004; Bridge et al., 2008; Manuel et al., 2010).

Despite the low number of isolates, the isoenzyme analysis using IEF was a useful tool to detect intraspecific variability among $C$. kahawae isolates and to separate $C$. kahawae from C. gloeosporioides. This study provides useful insights into the range of variability existing across these isolates. However, a more complete understanding of the genetic structure of $C$. kahawe populations would necessitate work on different geographical and spatial scales. From all the enzymatic systems studied, ALP was the most efficient to discriminate the two species and the only one apparently associated with aggressiveness. These studies are essential to improve coffee breeding, attaining higher levels of disease resistance towards a sustainable coffee production in African countries.

\section{ACKNOWLEDGEMENTS}

This work was partially funded by the EU Project ICA 4-CT-2001-10008 and by FCT fellowship POCI-2010/ SFRH/ BD/16684/2004.

\section{REFERENCES}

Abang MM, Winter S, Green KR, Hoffmann P, Mignouna HD, Wolf GA (2002) Molecular identification of Colletotrichum gloeosporioides causing yam anthracnose in Nigeria. Plant Pathology 51:63-71.

Bonde MR, Peterson GL, Maas JL (1991) Isozyme comparisons for identification of Colletotrichum species pathogenic to strawberry. Phytopathology 81:1523-1528.

Bridge PD, Waller JM, Davies D, Buddie AG (2008) Variability of Colletotrichum kahawae in relation to other Colletotrichum species from tropical perennial crops and the development of diagnostic techniques. Journal of Phytopathology 156:274-280.

Derso E, Waller JM (2003) Variation among Colletotrichum isolates from diseased coffee berries in Ethiopia. Crop Protection 22:561-565.

Guedes MEM (1988) Isozymes studies in compatible and incompatible Coffea arabica - Hemileia vastatrix interactions. Brotéria Genética LX:83-92.

Horvath BJ, Vargas Jr JM (2004) Genetic variation among Colletotrichum graminicola isolates from four hosts using isozyme analysis. Plant Disease 88:402-406.

Lima MLF, Menezes M (2002) Estudo comparativo de isolados de Colletotrichum graminicola através da análise eletroforética de padrões proteicos e isoenzimáticos. Fitopatologia Brasileira 27:12-16.

Lima Filho RM, Oliveira SMA, Menezes M (2003) Caracterização enzimática e patogenicidade cruzada de Colletotrichum spp. associados a doenças de pós-colheita. Fitopatologia Brasileira 28:620-625.

Loureiro A, Várzea V, Ribeiro A, Rodrigues Jr CJ (2004) Caracterização morfocultural, patogénica, bioquímica e molecular da variabilidade de Colletotrichum kahawae. Proceedings of the 
$4^{\text {th }}$ Congresso da Sociedade Portuguesa de Fitopatologia. Faro Portugal.

Lubbe CM, Denman S, Cannon PF, Groenewald JZ, Lamprecht SC, Crous PW (2004) Characterization of Colletotrichum species associated with diseases of Proteaceae. Mycologia 96:1268-1279.

Manga MB, Bieysse D, Mouen Bedimo JA, Akalay I, Bompard E, Berry D (1997) Observation sur la diversité de la population de Colletotrichum kahawae agent de l'anthracnose des baies du caféier Arabica. Implications pour l'améloration génétique. Proceedings of the Seventeenth International Conference on Coffee Science. Nairobi Kenya. pp. 604-612.

Manuel L, Talhinhas P, Várzea V, Neves-Martins N (2010) Characterization of Colletotrichum kahawae Isolates Causing Coffee Berry Disease in Angola. Journal of Phytopathology 158:310-313.

Nave EB, Sauhey VK (1986) Enzymatic changes in post-meiotic anther development in Petunia hybrida. I. Anther onthogeny and isoenzymes analyses. Journal of Plant Physiology 125:451-465.

Omondi CO, Hindorf H, Welz HG, Saucke D, Ayiecho PO, Mwang'ombe AW (1997) Genetic diversity among isolates of Colletotrichum kahawae causing coffee berry disease. Proceedings of the Seventeenth International Conference on Coffee Science. Nairobi Kenya. pp. 800-803.

Omondi CO, Ayiecho PO, Mwang'ombe AW, Hindorf $\mathrm{H}$ (2000) Reaction of some Coffea arabica genotypes to strains of Colletotrichum kahawae, the cause of coffee berry disease. Journal of Phytopathology 148:61-63.

Rego AM, Maffia LA, Alfenas AC (1994) Virulência e análise de isoenzimas de Colletotrichum orbiculare. Fitopatologia Brasileira 19:552-559.

Rios PRP, Silveira EB, Martins LSS, Silva Neto EB, Gomes AMA (2004) Caracterização de isolados de Colletotrichum lagenarium de pepino com base em marcadores isoenzimáticos. Horticultura Brasileira 22:729-733.

Robertson EF, Dannelly HK, Mallory PJ, Reeves HC (1987) Rapid isoelectric focusing in a vertical polyacrylamide minigel system. Analytical Biochemistry 167:290-294.

Scandalios JG (1969) Genetic control of multiple forms of enzymes in plants: A review. Biochemical Genetics 3:37-39.

Shaw CR, Prasad R (1970) Starch gel electrophoresis of enzymes - a compilation of recipes. Biochemical Genetics 4:297-320.

Silva D, Talhinhas P, Várzea V, Loureiro A, Silva MC, Paulo OS,
Batista D (2010) Population structure of Colletotrichum kahawae the causal agent of coffee berry disease (CBD) insights from a multi-locus approach. Proceedings of the $23^{\text {rd }}$ International Conference on Coffee Science. Bali Indonesia. pp. 529-536.

Silva MC, Várzea V, Guerra-Guimarães L, Azinheira HG, Fernandez D, Petitot A-S, Bertrand B, Lashermes P, Nicole M (2006) Coffee resistance to the main diseases: Leaf rust and coffee berry disease. Brazilian Journal of Plant Physiology 18:119-147.

Smith JA, Hammerschmidt R (1988) Comparative study of acidic peroxidases associated with induced resistance in cucumber, muskmelon and watermelon. Physiological and Molecular Plant Pathology 33:255-261.

Vallejos EC, 1983. Enzyme activity staining in isoenzymes. In: Tanksley SD, Orton TJ (Eds). Plant Genetics and Breeding, Part A. Amsterdam Netherlands: Elsevier Science Publishers. pp. 469516.

Van der Vossen HAM, Cook RTA, Marakaru GNW (1976) Breeding for resistance to coffee berry disease caused by Colletotrichum coffeanum Noack (sensu Hindorf) in Coffea arabica L. I. Methods of pre-selection for resistance. Euphytica 25:733-745.

Van der Vossen HAM, Walyaro DJ (2009) Additional evidence for oligogenic inheritance of durable resistance to coffee berry disease (Colletotrichum kahawae) in arabica coffee (Coffea arabica L.). Euphytica 165:105-111.

Várzea VMP (1995) 1. Variabilidade em Colletotrichum spp. de cafeeiro 2. Pesquisa de fontes de resistência ao C. kahawae. $\mathrm{PhD}$ Thesis. Instituto de Investigação Científica Tropical. Oeiras Portugal.

Várzea VMP, Rodrigues Jr CJ, Silva MC, Pedro JP, Marques DM (1999) High virulence of a Colletotrichum kahawae isolate from Cameroon as compared with other isolates from other regions. Proceedings of the $18^{\text {th }}$ International Conference on Coffee Science. Helsinki Finland.

Várzea VMP, Rodrigues Jr CJ, Lewis BG (2002) Distinguishing characteristics and vegetative compatibility of Colletotrichum kahawae in comparison with other related species from coffee. Plant Pathology 51:202-207.

Waller JM, Bridge PD, Black R, Hakiza G (1993) Characterization of the coffee berry disease pathogen, Colletotrichum kahawae sp. nov. Mycological Research 97:989-994.

Waller JM, Masaba DM (2006) The microflora of coffee surfaces and relationships to coffee berry disease. International Journal of Pest Management 52:89-96.

TPP 184 - Received 11 October 2011 - Accepted 7 December 2011 Section Editor: Eduardo S.G. Mizubuti 